İş ve İnsan Dergisi | The Journal of Human and Work

Y11 | Year: Ekim | October 2017

Cilt-Say1 | Volume-Issue: 4 (2)

ss | pp: $127-141$

doi: 10.18394/iid.321941

e-ISSN 2148-967X

http://dergipark.gov.tr/iid/

Araștırma Makalesi

\title{
Psikolojik Dayanıklılık İle Örgütsel Vatandaşık Davranışı Arasındaki İlişkide İş Doyumunun Aracılık Rolü: Havacılık Sektöründe Bir Araştırma $^{\text {a }}$
}

\section{The Mediating Role Of Job Satisfaction In The Relationship Between Resilience And Organizational Citizenship Behavior: A Research In Aviation Sector}

Engin Kanbur ${ }^{*}$, a Aysun Kanbur ${ }^{\mathrm{b}}$, Burak Özdemir ${ }^{\mathrm{c}}$

MAKALE BİLGİSI

Anahtar Kelimeler:

Psikolojik dayaniklılık

Örgütsel vatandaslık

davranıșı, İ̧s doyumu

\section{Tarihler:}

Geliş 16 Haziran 2017

Düzeltme geliș 18 Temmuz

2017

Kabul 27 Temmuz 2017

\begin{abstract}
ÖZ
Bu çalışmada, çalı̧̧anların psikolojik dayanıklılık düzeylerinin örgütsel vatandaşlık davranışı ve boyutları ile ilisskisinde is doyumunun aracılı (tam/kısmi) rolü incelenmistir. Araștırmanın örneklemi, havacllık sektöründe faaliyetlerini sürdüren bir işletmede görev yapan 263 çalışandan oluşmaktadır. Araştırmanın verileri anket tekniği kullanılarak toplanmıştır. Araştırmada; Psikolojik Dayanıklllık Ölçeği, Örgütsel Vatandaşlık Davranışı Ölçeği ve İş Doyumu Ölçeği kullanılmıştır. Araștırmada değişkenler arasındaki ilişkiyi ölçmek için korelasyon analizi, nedenselliği ölçmek için regresyon analizi ve aracılık rolünü ölçmek için ise hiyerarşik regresyon analizinden yararlanılmıștır. Araștırmanın bulgularına göre; psikolojik dayanıklllık ile örgütsel vatandaşlı davranışı ve iş doyumu arasında pozitif ve anlamlı bir iliş̧ki olduğu görülmüștür. Psikolojik dayanıklılığın örgütsel vatandașlık davranıșı ile ilișkisinde iș doyumunun kısmi aracılık etkisi olduğu saptanmıştır. Ayrıca, psikolojik dayanıklılığın örgütsel vatandaşlık davranışı alt boyutlarından vicdanllllk ve nezaket üzerindeki etkisinde iş doyumunun tam aracıllk etkisi, diğerkâmlık, centilmenlik ve sivil erdem üzerindeki etkisinde iş doyumunun kısmi aracılık etkisi olduğu vurgulanmaktadır.
\end{abstract}

\section{A R T ICLE INFO}

\section{Keywords:}

Resilience, Organizational citizenship behavior, Job satisfaction

\section{Article history:}

Received 16 June 2017

Received in revised form 18 July 2017

Accepted 27 July 2017

\begin{abstract}
A B S T R A C T
In this study, the mediating role (full/partial) of job satisfaction on the relationship between resilience levels of employees and their organizational citizenship behavior and its dimensions is investigated. Sample of the study consists of 263 employees who are working in an organization that continues its activities in aviation sector. Data of the research were collected by questionnaire technique. Resilience Scale, Organizational Citizenship Behavior Scale and Job Satisfaction Scale were utilized in the research. In the research, correlation analysis was used to measure the relationship between variables, regression analysis was used to measure the causality and hierarchical regression analysis was used to measure the mediating role. According to the findings of the research; there is a positive and significant relationship between resilience and organizational citizenship behavior and job satisfaction. It is found that job satisfaction has a partial mediating role on the relationship between resilience and organizational citizenship behavior. It is also emphasized that job satisfaction has a full mediating role on the effect of resilience on conscientiousness and courtesy as dimensions of organizational citizenship behavior and has a partial mediating role on the effect of resilience on altruism, sportsmanship and civic virtue as dimensions of organizational citizenship behavior.
\end{abstract}

\footnotetext{
${ }^{\circledR}$ Bu çalışma, 25- 27 Mayıs 2017 tarihlerinde yapılan 25. Ulusal Yönetim ve Organizasyon Kongresi'nde sunulmuş bildirinin genişletilmiş halidir.

*, a Iletișim Kurulacak Yazar, Yrd. Doç. Dr., Kastamonu Üniversitesi, Sivil Havacılık Yüksekokulu, Kastamonu, Türkive. ekanbur@kastamonu.edu.tr, ORCID:0000-0002-6261-9314

${ }^{b}$ Doç. Dr., Kastamonu Üniversitesi, İktisadi İdari Bilimler Fakültesi, Kastamonu, Türkiye. akanbur@kastamonu.edu.tr, ORCID: 00000002-5950-0865

${ }^{c}$ Yrd. Doç. Dr., Kastamonu Üniversitesi, İktisadi İdari Bilimler Fakültesi, Kastamonu, Türkiye.bozdemir@kastamonu.edu.tr, ORCID: 0000-0002-2710-4112
} 


\section{GíRiș}

Günümüz iş dünyasının rekabetçi ortamında, performanslarını arttırabilmek ve ayakta kalabilmek adına örgütlerin yakın ya da uzak çevresine olduğu kadar iç çevresine de odaklanması gerekmektedir. Örgütün iç çevresindeki en önemli unsur ise hiç şüphe yok ki örgütün çalışanlarıdır. Bu noktada çalışanlardan sergilenmesi beklenen ve örgüt tarafından arzulanan en önemli davranışlardan biri örgütsel vatandaşlık davranışı olarak görülmektedir. Örgütsel vatandaşlık davranışı, resmi olarak örgütün ödül sisteminde tanımlanmamıştır ancak çalışanların gönüllülüğünü esas alan bir olgudur (Markoczy, Vora \& Xin, 2009). Örgütsel vatandaşlık davranışından bahsetmek için; diğer çalışanlara ve hatta yeni katılanlara örgüte uyumlarında yardımcı olunan, dışarıda örgütten övgüyle bahsedilen ve zorunlu olmasa bile örgütün faaliyetleri için emek harcanan kısacası ekstra rol davranışının sergilendiği bir ortamdan bahsetmek gerekir (Bowling, Wang \& Li, 2012). Böyle bir ortamın sağlanmasında elbette ki çalışanların psikolojik dayanıklılıklarının rolü büyüktür. Psikolojik olarak dayanıklı olan çalışanlar aynı zamanda pozitif psikolojik sermaye sahibi kimselerdir ve psikolojik kapasitelerini geliştirme ve iyileştirme eğilimindedirler. Böylece örgütsel vatandaşlık davranışı sergilemeye de oldukça yatkın oldukları belirtilebilir.

Psikolojik olarak dayanıklı olan çalışanların iş doyumları yani çalışma yaşamından aldıkları haz ve mutluluğun daha fazla olacağı beklenmektedir. Psikolojisi pozitif yönde güçlü olan çalışanlar psikolojik dayanıklılıkları sayesinde en zorlu işlerin bile üstesinden gelerek işlerini etkin ve verimli şekilde gerçekleştirebilmektedir (Avey, Reichar, Luthans \& Mathre, 2011). Bu durum onların işlerinden duydukları gurur ve iş hazzını beraberinde getirmektedir. Diğer yandan işi ile gurur duyan, iş doyumu yüksek çalışanlar örgütsel vatandaşlık davranışı sergilemeye de daha yatkındır (Williams \& Anderson, 1991). İşte bu bilgiler 1şığında psikolojik dayanaklılığın örgütsel vatandaşlık davranışı üzerindeki etkisinde iş doyumunun aracı rolünü incelemek çalışmanın amacını oluşturmaktadır. Psikolojik dayanıklılık örgütsel vatandaşlık davranışını iş doyumu üzerinden mi etkilemektedir sorusunun cevab1 merak uyandırmakta ve çalışmada bu soruya yanıt aranmaktadir.

\section{KAVRAMSAL ÇERÇEVE}

\subsection{Psikolojik Dayanıklılık}

Psikolojik dayanıklılık, pozitif psikolojik sermayenin bir bileşeni olarak Luthans (2002) tarafından ortaya atılmış bir kavramdır. Pozitif psikolojik sermaye, bireyin verimliliği sağlaması amaciyla sosyal, ekonomik ve beşeri sermayeleri örgüte başarılı bir şekilde taşıyabilme yeteneği olarak tanımlanabilir (Erkutlu, 2015). Pozitif psikolojik sermaye kim olduğumuz ve pozitif gelişimle gelecekte ne olabileceğimiz üzerine odaklanır (Luthans, Luthans \& Luthans, 2004). Pozitif psikolojik sermaye ve dolayısıyla psikolojik dayanıklılık pozitif örgütsel davranış türlerinden biridir. Pozitif örgütsel davranış, pozitif yönlü insan kaynaklarının gücü ve psikolojik kapasitelerinin ölçülmesi, geliştirilmesi ve iyileştirilmesi için yapılan çalışma ve uygulamalar olarak tanımlanabilir (Luthans, 2002; Hodges \& Clifton, 2004; Luthans, Youssef \& Avolio, 2007; Carvajal, Jimenez, Hermosilla, Bejarano \& Vergel, 2010) ve temeli pozitif psikoloji kavramına dayanmaktadır (Donaldson ve Ko, 2010). Pozitif psikoloji ise, birey, grup ve örgüt etkileşimine ve gelişimine katk1 sağlayan süreç ve şartların incelenmesi, geliştirilmesi ve değerlendirilmesi olarak belirtilebilir (Seligman, 2002; Linley, Joseph, Harrington \& Wood, 2006).

Psikolojik dayanıklılık, bireyin birçok olumsuz olay karşısında (engellemeler, çatışma, belirsizlikler vb.) kendini toparlama gücü, sorumluluk alarak onlarla mücadele etme ve bu mücadelede başarılı olma yeteneği olarak açıklanabilir (Luthans, Avey, Avolio, Norman \& Combs, 2006; Avey vd., 2011; Çetin \& Basım, 2012; Bitmiş, Sökmen \& Turgut, 2013). Psikolojik dayanıklılık, stres kaynaklı olumsuzlukları azaltan ve uyumluluğu destekleyen kişisel bir özellik olarak görülmekte ve bazı kişilerin genetik özelliklerinden dolayı kuvvetli ve dirençli olarak doğduklarını öne sürmektedir. Ancak, alan yazındaki bazı araştırmalar, psikolojik dayanıklılığın sonradan öğrenilebilen bir kişilik özelliği olduğunu ortaya çıkarmaktadır. Psikolojik dayanıklılık, bireyin yüz yüze kaldığı gerçekler karşısında (tehditler, baskılar vb.) algılama sonucu fark edilen, öğrenilen ve gelişime açık bir süreç içeren kavram olarak tanımlanabilir (Beardslee \& Podorefsky, 1998; Basım \& Çetin, 2011).

Yazında psikolojik sermeye ve boyutlarından biri olan psikolojik dayanıklılıkla ilgili yapılan birçok araştırma ile pozitif ve negatif örgütsel davranış türleri arasındaki ilişkiler incelenmiştir. Psikolojik dayanıklılı̆̆ın iş doyumu, bağlılık, mutluluk, örgütsel vatandaşlık davranışı, çalışan performansı, 
güven, otantik liderlik, dönüşümcü liderlik, yaratıcılık ile pozitif bir ilişkisinin olduğu (Jensen ve Luthans, 2006; Walumbwa, Luthans, Avey \& Oke, 2009; Gooty, Gavin, Johnson, Frazier \& Snow, 2009; Avey, Luthans \& Youssef, 2010; Clapp-Smith, Vogelgesang \& Avey, 2009; Peterson, Luthans, Avolio, Walumbwa \& Zang, 2011; Avey vd., 2011; Rego, Sousa, Marques \& Cunha, 2011), sessizlik, işten ayrılma niyeti, iş stresi, tükenmişlik, iş-aile çatışması ve aile-iş çatışması ile negatif bir ilişkisinin (Avey vd., 2011; Wang, Liu, Wang \& Wang, 2012; Peng vd., 2013; Turgut, Bitmiş \& Sökmen, 2013) olduğu görülmektedir.

\section{2. Örgütsel Vatandaşlık Davranışı}

Örgütlerin değişen çevre koşullarına uyum sağlama ve sürdürebilirlik yolunda attıkları adımlar, örgütlerin çalışanlarının üzerlerine düșen görevlerden daha fazlasını yerine getirmelerini, diğer bir ifadeyle geleneksel görev performanslarının ötesinde davranmalarını gerekli kılmakta ve çalışanların gönüllü olarak sergiledikleri davranışlar önem kazanmaktadır (Bozkurt, 2011; Rafferty ve Restubog, 2011). Örgütlerde bu doğrultuda sergilenen davranışlar genel olarak "örgütsel vatandaşlık davranışı" ile açıklanmaktadır. Örgütsel vatandaşlık davranışı kavramı, ilk defa 1983 yılında Bateman ve Organ tarafindan ortaya konulmuştur (Gürbüz, 2010; Şeşen, 2010; Lambert, 2010). Bateman ve Organ'ın kavramsallaştırdığı örgütsel vatandaşlık davranışı; Barnard'ın 1928 y1lındaki "işbirliği için gönüllülük" biçimindeki imalı söylemine (Markoczy vd., 2009), Katz'ın (1964) çalışanların belirlenmiş rolleri ardındaki işbirlikçi davranışların örgütsel faaliyetlerin yürütülmesindeki önemini vurgulayan açıklamasına (Finkelstein, 2011), Katz ve Kahn'ın (1966) kavramsallaştırdıkları "Extra Rol Davranışı (Supra Role)"na (aktaran Demirel, Seçkin \& Özçınar, 2011) ve Dennis Organ (1977) tarafindan öne sürülen "doyum performansı artırır" konusundaki teoriye (Yücel \& Samanc1, 2009) dayanmaktadır.

Örgütsel vatandaşlık davranışı doğrudan, açıkça ve biçimsel olarak örgüt tarafindan ödüllendirilmeyen ekstra rol davranışıdır (Chiu, Tsai \& Ching, 2006; Gürbüz, 2006; Fox, Spector, Goh, Bruursema \& Kessler, 2012). Ekstra rol davranışının yanı sıra bağlamsal performans (Lee, Iijima \& Reade, 2011) olarak da adlandırılmaktadır. Organ (1988), örgütsel vatandaşlık davranışını örgütün resmi ödül sisteminde açık ve net bir şekilde belirtilmeyen, fakat bütüncül bir biçimde örgütün faaliyetlerini daha etkili ve verimli yürütmesini sağlayan, gönüllülüğe dayalı bireysel davranışlar olarak tanımlamaktadır (Paille, 2009; Baş \& Şentürk,
2011; Alessandri, Vecchione \& Tisak, 2012; Roberge, Xu \& Rousseau, 2012). İş arkadaşlarına yardımcı olmaya gönüllülük, yeni üyelerin örgüte uyumuna yardımc1 olma, örgüt ile ilgili dışarıdakilere olumlu yönde konuşma ve örgüt kimliğine yardımcı olacak zorunlu olmayan faaliyetlere katılma gibi örnekler bu açıklamaya uygun özel davranışlardır (Bowling vd., 2012).

Örgütsel vatandaşlık davranışı yazını incelendiğinde, örgütsel vatandaşlık davranışı boyutları ile ilgili çok farklı araştırmaların yapıldığı, ancak bu araştırmalarda boyutlar hakkında tam bir fikir birliğinin olmadığı görülmektedir (Buluç, 2008). Ancak yazında en çok tercih edilen ve kullanılan sınıflandırma Organ'ın açıkladığı ve diğerkâmlık, vicdanlılık, nezaket, centilmenlik ile sivil erdem olarak siraladığı beş temel boyut ön plana çıkmaktadır (Hemdi \& Nasurdin, 2007; Keleş \& Pelit, 2009; Sökmen \& Boylu, 2011; Yücel \& Demirel, 2012; Rurkkhum \& Bartlett, 2012). Diğerkâmlık, çalışanın örgütte yürütülen işler ile ilgili bir sorun ve/veya görev ortaya çıktığında diğer çalışanlara yardımcı olmayı amaçlayan gönüllük esaslı davranışları ifade etmektedir. Vicdanlılık, çalışanların iş ile ilgili kendilerinden istenen temel rol davranışının üzerinde bir rol davranışı sergilemeleri üzerinde durmaktadır. Nezaket, örgütte faaliyetlerin yürütülmesi için yapılan işbölümünden dolayı etkileşim halindeki çalışanların olumlu iletişim kurmalarını ifade etmektedir. Centilmenlik, örgütte çalışanlar arasında gerginlik ve çatışma oluşturabilecek olumsuz durumlardan uzak durulmasını belirtmektedir. Sivil erdem, esas olarak örgütte yürütülen faaliyetlere aktif ve gönüllü olarak katılım üzerinde durmaktadır (Organ, 1997; İrmiş \& Gök, 2008; Can \& Özer, 2011).

\section{3. İş Doyumu}

İş doyumu, bireyin genel anlamda çalışma hayatından duyduğu haz ve mutluluk olarak tanımlanabilir. Landy'e göre iş doyumu, iş ile ilgili bireyin değerlendirmeleri sonucu oluşan duygusal durum veya reaksiyon şeklinde belirtilebilir (Keser, 2006; Şahin, 2011). İş doyumu, bireylerin yaptıkları işe, çalıştıkları iş yerlerine veya birlikte çalıştıkları iş arkadaşlarına yönelik duygu, düşünce ve davranışlarının bir çıktısı olarak içsel değerlendirmelerini ve işlerine yönelik genel tutumlarını ifade etmektedir (Yıldırım, 2007). Ayrıca iş doyumu, kişinin yaptığ 1 işe gösterdiği sayg1 neticesinde oluşan pozitif tutumlarını içermektedir. Değişen bir yapısı olan iş doyumunun, örgüt içinde bir defa sağlanması devamlı aynı düzeyde kalacağı veya değişmeyeceği anlamına gelmez (Şeker \& Zirhlığlu, 2009; Sparks, Corcoran, Nabors \& Hovanitz, 2005). İş 
doyumunu; kariyer firsatlarının varlığı, bireylerarası ilişkiler, ekonomik getiriler, çalışma ve ergonomik şartlar etkilemektedir. Bu kapsamda bireyin iş doyumunun gerek dışsal gerekse de içsel bazı unsurlardan etkilendiği söylenebilir (Kılıç, Efeoğlu, Mimaroğlu \& Özgen, 2008).

İş doyumu, bireylerin görev ve sorumluluklarında başarıyı elde edebilmesi ve sürdürebilmesi, mutlu olabilmesi, pozitif örgütsel davranışlarda bulunabilmesi, negatif örgütsel davranışlardan kaçınabilmesi, daha üretken, verimli ve performanslı olabilmesi için gerekli olan motivasyon araçlarından biridir (Sünter, Canbaz, Dabak, Öz \& Pekşen, 2006). İş doyumunun dayandığı temelleri açıklamak için ortaya konan kuramların birçoğu iş doyumunun motivasyon ile yakın ilişkisinin olduğunu söylemektedir. Maslow'un "İhtiyaçlar Hiyerarşisi”, Adams'ın "Eşitlik Kuramı”, Vroom'un "Beklenti Kuramı", Salancik ve Pfeffer'ın 'Kişilerarası Karşılaştırma Kuramı", Blau'nun "Sosyal Mübadele Kuramı", Herzberg'in "Çift Hijyen Kuramı", Eisenberger'ın “Örgütsel Destek Kuramı" gibi birçok kuramın temeli, bireyin güdülenmesi ve neticesinde yaptığ işten haz alması ve/veya doyum sağlamasıdır (Eğinli, 2009).

Yazında iş doyumu ile diğer pozitif ve negatif örgütsel davranış türleri arasında birçok araştırma gerçekleştirilmiştir. İş doyumunun; iş performansı, örgütsel bağlılık, örgütsel vatandaşlık davranışı, çalışan tutumları ve temel benlik değerlendirmesi (Iaffaldano, Michelle \& Muchinsky, 1985; Williams ve Anderson, 1991; Judge, Thoresen, Bono \& Patton, 2001; Saari ve Judge, 2004; Gürbüz, Erkuş \& Sığrı, 2010) ile pozitif yönlü, tükenmişlik, işten ayrılma niyeti, iş aile çatışması ve stres (Jayaratne ve Wayne, 1984; Tett ve Meyer, 1993; Naima, 1998; Bruck, Allen \& Spector, 2002) ile negatif yönlü bir ilişkisinin olduğu görülmektedir.

\subsection{Psikolojik Dayanıklılık, Örgütsel Vatandaşıı Davranışı, İş Doyumu İlişkisisi}

Psikolojik dayanıklılık, çalışanların örgüt içerisinde karşılaştıkları ve performanslarını olumsuz etkileyebilecekleri birçok olayın farkında olması ve bunlar ile mücadele edebilecek yetenek ve bilgiye sahip olmasıdır. $\mathrm{Bu}$ bağlamda, psikolojik dayanıklılık seviyeleri yüksek olan bireylerin ekstra rol davranışı olan örgütsel vatandaşlık davranışı gösterme eğiliminde oldukları yazında gerçekleştirilen bazı araştırmalarla da desteklenmektedir (Lifeng, 2007; Avey vd., 2010; Avey vd., 2011; Budak, 2015).
Hipotez 1: Çalışanların psikolojik dayanıklılık düzeyleri örgütsel vatandaşlık davranışını pozitif etkiler.

Psikolojik dayanıklılık ile iş doyumu arasındaki ilişkinin pozitif ve anlamlı olduğunu gösteren çalışmalar da bulunmaktadır (Özer, Topaloğlu \& Özmen, 2013; Hungins, 2016). Belirsizlikler, çatışmalar, engellemeler, başarısızlıklar karşısında üstlenilen sorumluluk, sahip olunan bilgi, yetenek ve pozitif psikoloji olarak da tanımlanan psikolojik dayanıklılı̆̆ın iş doyumu ile yakın bir ilişkisinin olduğu belirtilebilir. Psikolojik dayanıklılık seviyesi yüksek olan çalışanların işten sağlayacağı doyumunda yüksek olacağı söylenmektedir (Çetin \& Basım, 2011).

Hipotez 2: Çalışanların psikolojik dayanıklılık düzeyleri iş doyumlarını pozitif etkiler.

Sosyal Mübadele Kuramı, Karşılıklılık Normu, Örgütsel Destek Kuramı gibi kuramların gereği; bireylerin işlerinden sağlayacağı doyum düzeyleri ne kadar yüksek olursa, onların örgütlerine daha bağlı olacağı ve örgütsel vatandaşlık davranışları gösterecekleri yazında vurgulanmaktadır (Williams ve Anderson, 1991).

Hipotez 3: Çalışanların iş doyumu örgütsel vatandaşlık davranışlarını pozitif etkiler.

Martin Seligman (2002) tarafindan ortaya atılan pozitif psikoloji, psikoloji biliminin bireylerin normal olmayan, negatif yönleri üzerine odaklandığını ancak bireyin güçlü ve pozitif yönlerinin de olduğunu ve bunun iyi anlaşılıp, yönetilmesi ve geliştirilmesi gerektiğini belirtmektedir. $\mathrm{Bu}$ bağlamda pozitif psikoloji, bireyin mutlu, huzurlu, başarılı, güçlü ve iyi olabileceğine dair yönlerini göstermekte önemli bir role sahiptir (Keleş, 2011; Linley vd., 2006). Bireylerin pozitif psikoloji bakış açısıyla sahip oldukları yüksek psikolojik dayanıklılık düzeyleri onların işe ilişkin tüm zorlukların üstesinden gelebilmelerini sağlayacak ve işten sağladıkları doyumu yükseltecektir. Dolayısıyla işten sağladığı doyumu yüksek olan bireyin biçimsel olmayan ve gönüllülük temeline dayalı örgütsel vatandaşlık davranışı sergileyeceği belirtilebilir. Böylece psikolojik dayanıklılık düzeyleri yüksek olan bireylerin de ekstra rol davranışı olan örgütsel vatandaşlık davranışı göstermelerini sağlayacaktır (Murphy, Athanasou \& King, 2002; Foote ve Tang, 2008; Y1lmaz, 2012). Ayrica, yazında daha önce değişkenler arasındaki aracılık etkinin incelendiği bir çalışmaya rastlanılmaması bu konudaki bulguların önemini arttırmaktadır. 
Hipotez 4: Çalışanların psikolojik dayanıklılık düzeylerinin örgütsel vatandaşlık davranışları üzerindeki etkisinde iş doyumunun aracılık rolü vardir.

Hipotez 4a: Çalışanların psikolojik dayanıklılık düzeylerinin örgütsel vatandaşlık davranışlarının "diğerkâmlık" boyutu üzerindeki etkisinde iş doyumunun aracılık rolü vardır.

Hipotez 4b: Çalışanların psikolojik dayanıklılık düzeylerinin örgütsel vatandaşlık davranıșlarının "vicdanlılık" boyutu üzerindeki etkisinde iş doyumunun aracılık rolü vardır.

Hipotez 4c: Çalıșanların psikolojik dayanıklılık düzeylerinin örgütsel vatandaşlık davranışlarının "nezaket" boyutu üzerindeki etkisinde iş doyumunun aracılık rolü vardır.

Hipotez 4d: Çalışanların psikolojik dayanıklılık düzeylerinin örgütsel vatandaşlık davranışlarının "centilmenlik" boyutu üzerindeki etkisinde iş doyumunun aracılık rolü vardır.

Hipotez 4e: Çalışanların psikolojik dayanıklılık düzeylerinin örgütsel vatandaşlık davranışlarının "sivil erdem" boyutu üzerindeki etkisinde iş doyumunun aracılık rolü vardır.

\section{YÖNTEM}

\subsection{Araştırmanın Amacı ve Önemi}

Araştırmanın temel amacı; çalışanların psikolojik dayanıklılık düzeylerinin örgütsel vatandaşlık davranışları ve boyutları üzerindeki etkisinde iş doyumunun aracilık (tam/kısmi) rolünün irdelenmesidir. Çalışanların iş doyumunu etkileyen birçok farklı unsur bulunmaktadır. Bunlardan birisi de çalışanların sahip olduğu psikolojik dayanıklılık düzeyi olarak ifade edilmektedir (Çetin \& Basım, 2011; Erkuş \& Fındıklı, 2013). Çalışanların psikolojik dayanıklılık düzeylerinin yüksek olması belirsizlikler, engellemeler, çatışmalar, tehditler, baskılar gibi olumsuzluklar ile mücadele edebilmesi ve başarılı olabilmesini sağlayacaktır. Bu durum çalışanların işten sağladığı doyumu yükseltecektir. İş doyumu yüksek olan çalışanın örgüte olan bağlılı̆̆ artacak ve dolayısıyla ekstra rol davranışı olan örgütsel vatandaşlık davranışı sergileyecektir. Örgütlerin rakipleri karşısında sürdürülebilir rekabet avantajı sağlamasında ve amaçlarına ulaşmasında çalışanların sergileyecekleri örgütsel vatandaşlık davranışı çok önemlidir. Çalışanların örgütsel başarının sağlanmasında ödül beklemeksizin kendi görev tanımları dışında sergileyecekleri ve örgütsel vatandaşlık davranışı olarak tanımlanan davranışların etkisi oldukça yüksektir.

\subsection{Araștırmanın Evreni, Örneklemi ve Kısıtları}

Araştırma evrenini, havacılık sektöründe faaliyetlerini sürdüren bir işletmedeki 350 çalışan oluşturmaktadır. Araştırmada kolayda örnekleme yöntemi kullanılmıştır. Araştırma sürecinde 300 anket formu işletmeye gönderilmiş ve \%87,6 yanıtlanma oranıyla 263 anketin geri dönüşümü sağlanmış olup, araştırma evrenini temsil edecek niteliktedir (Altunışık, Coşkun, Bayraktaroğlu \& Yıldırım, 2004: 125). Araştırmanın kısıtları; araştırmanın havacılık sektöründe faaliyetlerini sürdüren bir işletmedeki çalışanlarla yapılması, veri toplama aracı olarak anket yönteminden yararlanılması ve kullanılan ölçeklerle sınırlandırılması olarak değerlendirilebilir.

\subsection{Araştırmanın Veri Toplama Yöntemi ve Ölçekleri}

Araştırma verilerinin güvenilir bir şekilde toplanabilmesi ve araştırma hipotezlerinin test edilebilmesi amacıyla anket tekniği kullanılmıştır. Araştırmada katılımcıların psikolojik dayanıklılık düzeylerini belirlemek amaciyla, Luthans, Avolio, Avey ve Norman (2007) tarafindan geliştirilen ve Çetin ve Basım (2012) tarafından Türkçe'ye uyarlanan "Psikolojik Sermaye Ölçeği" boyutlarından biri olan geçerliliği ve güvenilirliği $(\alpha=68)$ kanıtlanmış "Psikolojik Dayanıklılık Alt Boyut Ölçeği” kullanılmıştır. Ölçek, altı soru ve tek boyuttan oluşmaktadır. Ölçekte, "Eğer zorunda kalırsam, işimde kendi başıma yeterim" ve "İşimdeki zorlukları genellikle bir şekilde hallederim" gibi sorular yer almaktadır.

Katılımcıların örgütsel vatandaşlık davranışlarını belirlemek için, Vey ve Campbell (2004) ile Williams ve Shiaw (1999) çalışmalarından yararlanılarak Basım ve Şeşen (2006) tarafından hazırlanan $(\alpha=89)$ ve Türkçeye uyarlanan, Sökmen ve Boylu (2011) $(\alpha=.91)$ ve Çetin, Korkmaz ve Çakmakçı (2012) $(\alpha=.92)$ tarafindan çalışmalarında yararlanılan, geçerliliği ve güvenilirliği kanıtlanmış "Örgütsel Vatandaşlık Davranışı Ölçeğ kullanılmıştır. Ölçek; diğerkâmlık, vicdanlılık, nezaket, centilmenlik, sivil erdem olmak üzere beş boyuttan ve 19 sorudan oluşmakta ve "İş esnasında sorunla karşılaşan kişilere yardım etmek için gerekli zamanı ayırırım" ve "Mesai içerisinde kişisel işlerim için zaman harcamam" gibi sorular yer almaktadır.

Katılımcıların iş doyum düzeylerini ölçmek amaciyla, Brayfield ve Rothe (1951) tarafindan 
Tablo l. Faktör ve Güvenilirlik Analizi

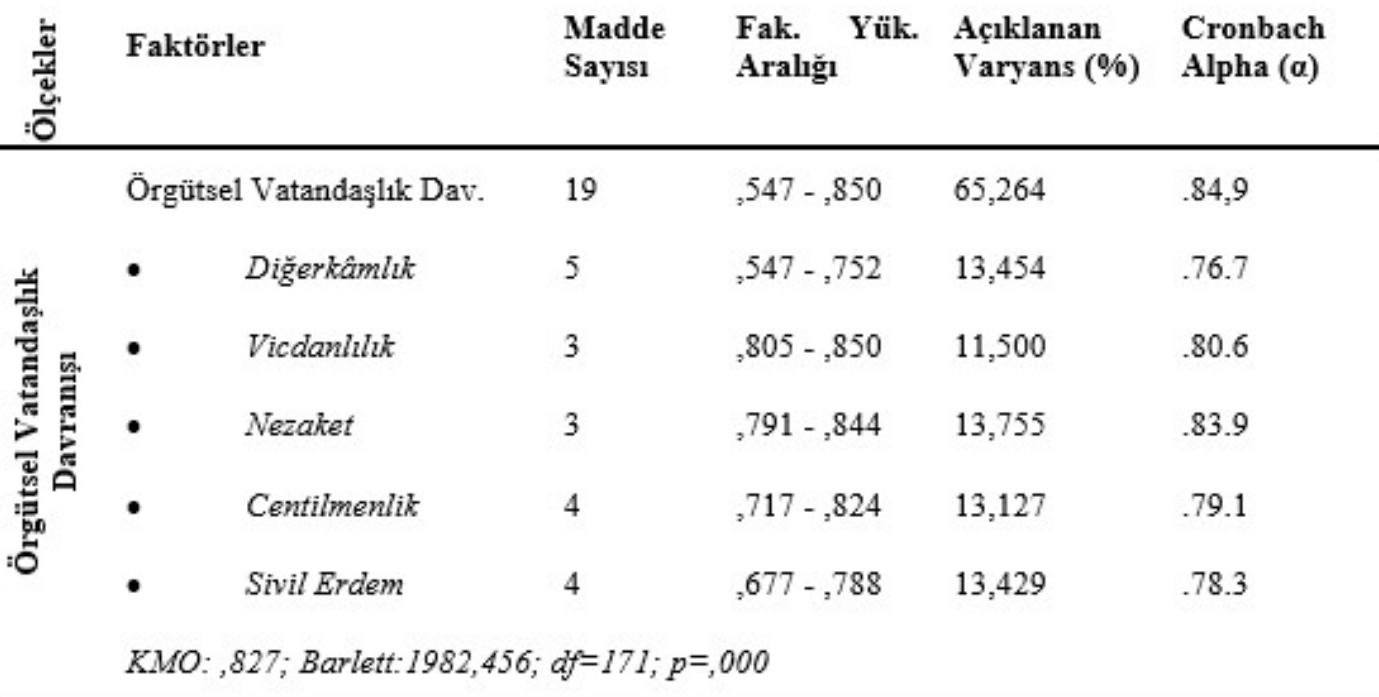

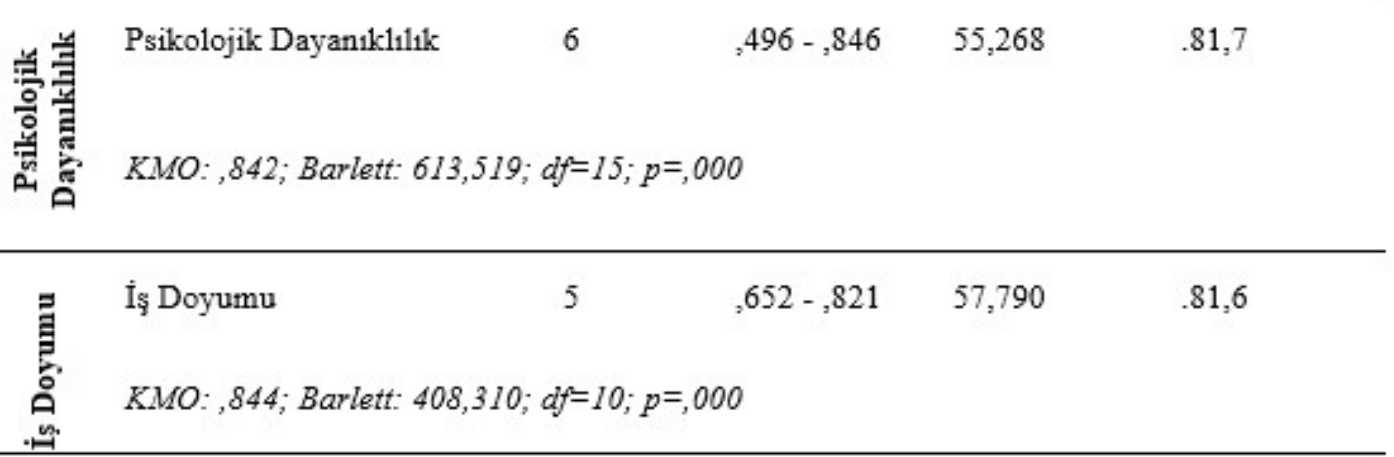

geliştirilen ve Bilgin (1995) tarafindan Türkçeye uyarlanan ve Keser (2006) $(\alpha=76,2)$ tarafindan çalışmasında yararlanılan, geçerliliği ve güvenilirliği kanıtlanmış "Işs Doyumu Ölçeği" kullanılmıştır. Ölçek, beş soru ve tek boyuttan oluşmaktadır. Ölçekte, "Mutluluğu, en çok ișimdeyken buluyorum" ve "İsyerinde zaman geçmek bilmiyor” gibi sorular yer almaktadır.
Ölçeklerin puanlaması, 5'li likert ölçeğine uygundur ( 1 =kesinlikle katılmiyorum; 5=kesinlikle kat1lıyorum).

\subsection{Faktör Analizi ve Güvenilirlik Analizi}

Araştırmada kullanılacak ölçeklerin yapısal geçerliliğini test etmek amacıyla faktör analizi ile

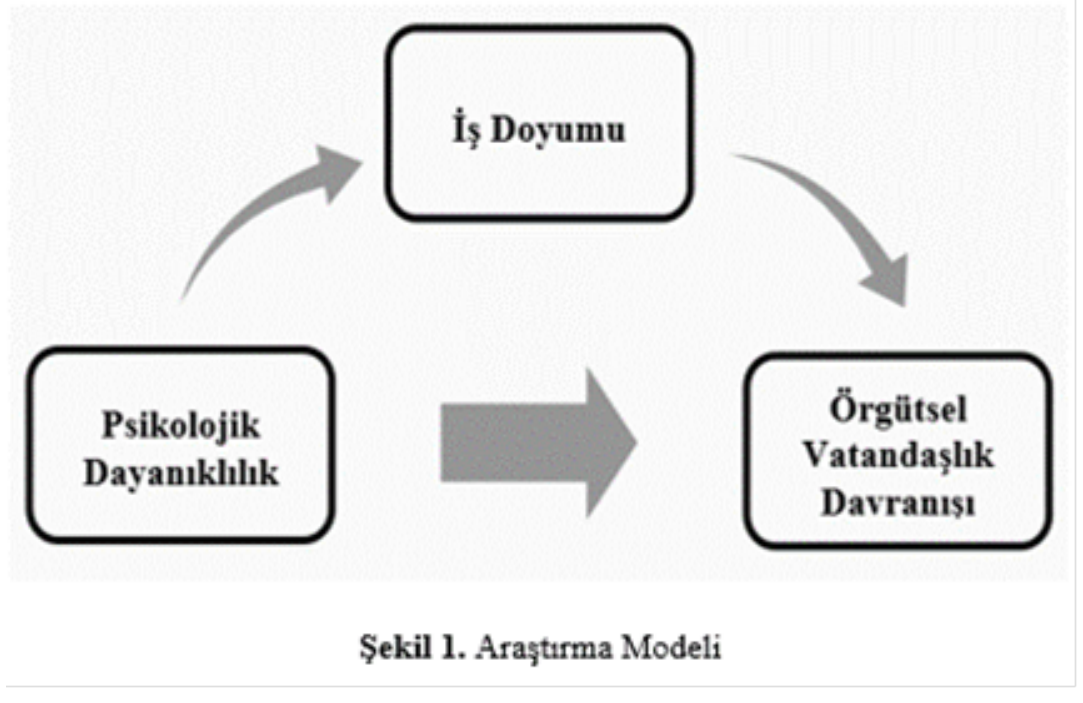


güvenilirlik analizi (Cronbach Alfa) gerçekleştirilmiş ve bulgular Tablo 1'de sunulmuştur.

Faktör analizi bulguları sonucunda ortaya çıkan faktör yapısı kapsamında oluşturulan araştırma modeli Şekil 1'de gösterilmektedir.

\section{BULGULAR}

$\mathrm{Bu}$ bölümde, araștırma değişkenleri arasındaki ilişkiyi belirlemek üzere korelasyon analizi, değişkenler arasındaki nedensellik ilişkisini ortaya koymak için regresyon analizi ve aracılık etkisinin olup olmadığını test etmek için ise hiyerarşik regresyon analizi kullanılmıştır.

\subsection{Korelasyon Analizi}

Çalışmada, değişkenler arasındaki ilişkiyi ölçmek amacıyla korelasyon analizinden yararlanılmıştır (Tablo 2).

Tablo 2'de yer alan, psikolojik dayanıklılık, örgütsel vatandaşlık davranışı ve alt boyutları ile iş doyumu değişkenleri arasındaki korelasyon analizine ilişkin bulgular incelendiğinde; psikolojik dayanıklılık ile örgütsel vatandaşlık davranışı $(\mathrm{r}=, 423 ; \mathrm{p}<, 01)$ ve alt boyutlarından diğerkâmlık $(\mathrm{r}=, 292 ; \mathrm{p}<, 01)$, vicdanlılı $(\mathrm{r}=, 172 ; \mathrm{p}<, 01)$, nezaket $(\mathrm{r}=, 258 ; \mathrm{p}<, 01)$, centilmenlik $(\mathrm{r}=, 261 ; \mathrm{p}<, 01)$, sivil erdem $(\mathrm{r}=, 407 ; \mathrm{p}<, 01)$ ve iş doyumu $(\mathrm{r}=, 375 ; \mathrm{p}<, 01)$ arasında pozitif yönde ve anlamlı bir ilişkinin olduğu görülmektedir.

\subsection{Regresyon Analizi}

Araştırmada, değişkenler arasındaki nedenselliği ölçmek için yapılan regresyon analizi Tablo 3'te, aracılık rolünü tespit etmek için yapılan hiyerarşik regresyon analizi ise Tablo 4 ve 5 'te sunulmaktadir. Ayrıca, Durbin-Watson istatistiği değeri ile atık değerler arasındaki otokorelasyonun varlığ edilmiştir.

Tablo 3'te yer alan regresyon analizi bulguları değerlendirildiğinde; örgütsel vatandaşlık davranış1 değişkeninin \%17,9'unun psikolojik dayanıklılık değişkeni tarafindan açıklandı̆̆ $\left(\mathrm{R}^{2}=, 179\right)$ ve $56,975 \mathrm{~F}$ değeri ile \%99 güven aralığında $(\mathrm{p}<0,01)$ anlamlı olduğu görülmektedir. Bulgulara göre; çalışanların psikolojik dayanıklılık düzeylerinin örgütsel vatandaşlık davranışlarını pozitif etkilediği (H1) kabul edilmektedir $(\beta=, 423, p=, 000)$. İş doyumu değişkeninin \%14,1'inin psikolojik dayanıklılık değişkeni tarafından açıklandı̆̆ $\left(\mathrm{R}^{2}=, 141\right)$ ve $42,685 \mathrm{~F}$ değeri ile $\% 99$ güven aralığında $(\mathrm{p}<0,01)$ anlamlı olduğu görülmektedir. Bulgular 1şı̆̆ında; çalışanların psikolojik dayanıklılık düzeylerinin iş doyumlarını pozitif olarak etkilediği $(\mathrm{H} 2)$ kabul edilmektedir $(\beta=, 375$, $\mathrm{p}=, 000)$. Örgütsel vatandaşlık davranışı değişkeninin \%42,8'inin iş doyumu değişkeni tarafindan açıklandı $\breve{g}_{1}\left(R^{2}=, 428\right)$ ve 195,246 F değeri ile \%99 güven aralığında $(p<0,01)$ anlamlı olduğu görülmektedir. Bulgular 1şığında, çalışanların iş doyumunun örgütsel vatandaşlık davranışlarını pozitif olarak etkilediği (H3) kabul edilmektedir $(\beta=, 654, p=, 000)$. Tüm analizlerde atık değerler arasında otokorelasyon olmadı ğ 1 ( $\mathrm{DW}=1,5$ $-2,5$ arası) söylenebilir.

Tablo 2. Korelasyon Analizi ve Bulgular1

\begin{tabular}{|c|c|c|c|c|c|c|c|c|c|c|c|}
\hline \multicolumn{2}{|c|}{ Değișkenler } & \multirow{2}{*}{$\begin{array}{l}\text { Ort. } \\
3,916\end{array}$} & \multirow{2}{*}{$\begin{array}{l}\text { S.S. } \\
, 6344\end{array}$} & \multirow{2}{*}{$\frac{1}{1}$} & \multirow[t]{2}{*}{2} & \multirow[t]{2}{*}{3} & \multirow[t]{2}{*}{4} & \multirow[t]{2}{*}{5} & \multirow[t]{2}{*}{6} & \multirow[t]{2}{*}{7} & $\varepsilon$ \\
\hline 1 & Psikolojik Dayaniklilik & & & & & & & & & & \\
\hline 2 & $\begin{array}{l}\text { Örgütsel Vatandaşlik } \\
\text { Davranış1 }\end{array}$ & 4,165 &, 4221 &, $423 *$ & 1 & & & & & & \\
\hline 3 & Diğerkâmlık & 4,348 &, 5695 &, $292 *$ &, $645^{*}$ & 1 & & & & & \\
\hline 4 & Vicdanllltk & 3,998 &, 7890 &, $172 *$ &, $577^{*}$ &, 112 & 1 & & & & \\
\hline 5 & Nezaket & 4,636 &, 5639 &, $258 *$ &, $654^{*}$ &, $442^{*}$ &, $282 *$ & 1 & & & \\
\hline 6 & Centilmenlik & 3,831 &, 6962 & $261^{*}$ &, $707^{*}$ &, $220 *$ &, $292 *$ &, $283^{*}$ & 1 & & \\
\hline 7 & Sivil Erdem & 4,042 &, 6109 &, $407^{*}$ &, $719 *$ & $287^{*}$ & $267 *$ &, $344^{*}$ & $447^{*}$ & 1 & \\
\hline 8 & İş Doyumu & 4,275 &, 5566 &, $375^{*}$ &, $654^{*}$ &, $516^{*}$ &, $386^{*}$ &, $555^{*}$ &, $338 *$ &, $402 *$ & 1 \\
\hline
\end{tabular}


Tablo 3. Değiş̧kenler Arasındaki İlişkilere Yönelik Regresyon Analizleri ve Bulguları

Bağımlı Değișken: Ōrgütsel Vatandaşlik Davranı̧̧ı

\begin{tabular}{lllllll}
\hline Bağımsız değișken & $\mathbf{R}^{2}$ & $\mathbf{F}$ & $\mathbf{B}$ & $\mathbf{t}$ & $\mathbf{P}$ & $\mathbf{D W}$ \\
\hline Psikolojik Dayanıklılik & 17,9 & 56,975 &, 423 & 7,548 &, $000^{*}$ & 1,873 \\
İş Doyumu & 42,8 & 195,246 &, 654 & 13,973 &, $000^{*}$ & 1,966 \\
\hline
\end{tabular}

Bağımlı Değișken: İş Doyumu

\begin{tabular}{lllllll}
\hline Bağımsız değișken & $\mathbf{R}^{2}$ & $\mathbf{F}$ & $\boldsymbol{\beta}$ & $\mathbf{t}$ & $\mathbf{P}$ & $\mathbf{D W}$ \\
\hline Psikolojik Dayanıklılık & 14,1 & 42,685 &, 375 & 6,533 &, $000^{*}$ & 1,812 \\
\hline
\end{tabular}

${ }^{*} \mathrm{p}<0.01$ düzeyinde anlamlıdır.

\subsection{Hiyerarşik Regresyon Analizi}

Araştırmada, "çalışanların psikolojik dayanıklılık düzeylerinin örgütsel vatandaşlık davranışları üzerindeki etkisinde iş doyumunun aracılık rolü vardır" temel hipotezini (H4) ve alt boyutlara (H4a, $\mathrm{H} 4 \mathrm{~b}, \mathrm{H} 4 \mathrm{c}, \mathrm{H} 4 \mathrm{~d}$ ve H4e) ait hipotezleri test etmek amacıyla hiyerarşik regresyon analizi kullanılmıştır.
Yapılan analiz ve bulguları Tablo 4 ve 5'te ayrıntılı olarak sunulmaktadır. Psikolojik dayanıklılık değişkeninin örgütsel vatandaşlık davranışı değişkeni üzerindeki etkisinde iş doyumu değişkeninin aracılık rolünü test etmek için hiyerarşik regresyon analizinden yararlanılmıştır. Bu analize göre (Baron \& Kenny, 1986; Turunç \& Çelik, 2010; Akkoç, Çalışkan \& Turunç, 2012);

Tablo 4. Değişkenler Arasındaki Aracıllk Rolünü İncelemeye Yönelik Hiyerarşik Regresyon Analizi ve Bulguları

$\underline{\text { Model } 1}$

\begin{tabular}{|c|c|c|c|c|c|c|c|}
\hline Bağımsız Değișken & Bağımlı D & șken & $\mathbf{R}^{2}$ & $\mathbf{F}$ & $\beta$ & t & $\mathbf{P}$ \\
\hline Psikolojik Dayaniklilik & $\begin{array}{l}\text { Örgütsel } \\
\text { Davranışı }\end{array}$ & Vatandaşlik & 17,9 & 56,975 &, 423 & 7,548 &, $000 *$ \\
\hline
\end{tabular}

$\underline{\text { Model } 2}$

\begin{tabular}{lllllll} 
Bağımsız Değișken & Bağımlı Değișken & $\mathbf{R}^{2}$ & $\mathbf{F}$ & $\boldsymbol{\beta}$ & $\mathbf{t}$ & $\mathbf{P}$ \\
\hline Psikolojik Dayanılklılik & İş Doyumu & 14,1 & 42,685 &, 375 & 6,533 &, $000^{*}$ \\
\hline
\end{tabular}

$\underline{\text { Model } 3}$

\begin{tabular}{llllllll} 
Bağımsız Değișken & Bağımlı Değișken & $\mathbf{R}^{2}$ & $\mathbf{F}$ & $\boldsymbol{\beta}$ & $\mathbf{t}$ & $\mathbf{P}$ & \\
\hline Psikolojik Dayanıklılık & $\begin{array}{l}\text { Örgütsel } \\
\text { Davranışı }\end{array}$ & Vatandaşlik & 46,5 & 112,910 & ,207 & 4,233 &, $000^{*}$ \\
\hline İş doyumu & & & &, 577 & 11,780 &, $000^{*}$ \\
\hline
\end{tabular}

*p<0.01 düzeyinde anlamlidır.

Sobel $Z=5.748, p=0.00$ 
Tablo 5. Değişkenler (Alt Boyutlar) Arasındaki Aracılık Rolünü İncelemeye Yönelik Hiyerarşik Regresyon Analizi ve Bulgulan

\begin{tabular}{|c|c|c|c|c|c|c|c|}
\hline $\begin{array}{l}\text { Bağımsız } \\
\text { Değișken }\end{array}$ & $\begin{array}{l}\text { Bağımlı } \\
\text { Değișken }\end{array}$ & $\mathbf{R}^{2}$ & F & $\beta$ & t & p & $\begin{array}{l}\text { Sobel } \\
\text { Testi }\end{array}$ \\
\hline Psikolojik Dayamıklılık & İş Doyumu & 14,1 & 42,685 &, 375 & 6,533 &, $000^{\circ}$ & \\
\hline \multicolumn{8}{|l|}{ Model 1} \\
\hline Psikolojik Dayamıklılık & \multirow{3}{*}{ Diğerkâmllk } & 8,5 & 24,292 &, 292 & 4,929 &, $000^{\circ}$ & \multirow{3}{*}{$\begin{array}{l}Z=5.167 \\
P=0,00\end{array}$} \\
\hline Psikolojik Dayamıklulik & & \multirow{2}{*}{27,7} & \multirow{2}{*}{49,923} &, 114 & 2,013 &, $045^{88}$ & \\
\hline İş Doyumu & & & &, 473 & 8,319 &, $000^{8}$ & \\
\hline \multicolumn{8}{|l|}{ Model 2} \\
\hline Psikolojik Dayamiklıllk & \multirow{3}{*}{ Vicdanlllik } & 3,0 & 7,956 &, 172 & 2,821 &, $005^{8}$ & \multirow{3}{*}{$\begin{array}{l}\mathrm{Z}=4.475 \\
\mathrm{P}=0,00\end{array}$} \\
\hline Psikolojik Dayamıklulik & & \multirow{2}{*}{15,0} & \multirow{2}{*}{22,955} &, 032 &, 513 & 609 & \\
\hline İş Doyumu & & & &, 374 & 6,071 &, $000^{8}$ & \\
\hline \multicolumn{8}{|l|}{ Model 3} \\
\hline Psikolojik Dayamiklllık & \multirow{3}{*}{ Nezaket } & 6,6 & 18,576 &, 258 & 4,310 &, $000^{\circ}$ & \multirow{3}{*}{$\begin{array}{l}\mathrm{Z}=5.438 \\
\mathrm{P}=0,00\end{array}$} \\
\hline Psikolojik Dayamıklllık & & \multirow{2}{*}{31,1} & \multirow{2}{*}{58,724} &, 058 & 1,039 &, 300 & \\
\hline İş Doyumu & & & &, 534 & 9,611 &, $000^{*}$ & \\
\hline \multicolumn{8}{|l|}{ Model 4} \\
\hline Psikolojik Dayamıklılık & \multirow{3}{*}{ Centilmenlik } & 6,8 & 19,035 &, 261 & 4,363 &, $000^{8}$ & \multirow{3}{*}{$\begin{array}{l}\mathrm{Z}=3.371 \\
\mathrm{P}=0,00\end{array}$} \\
\hline Psikolojik Dayamıklılık & & \multirow{2}{*}{13,5} & \multirow{2}{*}{20,313} &, 156 & 2,506 &, $013^{* 8}$ & \\
\hline İs Doyumu & & & &, 280 & 4,494 &, $000^{\circ}$ & \\
\hline \multicolumn{8}{|l|}{ Model 5} \\
\hline Psikolojik Dayamıklulik & \multirow{3}{*}{ Sivil Erdem } & 16,6 & 51,867 &, 407 & 7,202 &, $000^{\circ}$ & \multirow{3}{*}{$\begin{array}{l}Z=3.973 \\
P=0,00\end{array}$} \\
\hline Psikolojik Dayanıklılık & & \multirow{2}{*}{23,8} & \multirow{2}{*}{40,650} & 298 & 5,109 &, $000^{*}$ & \\
\hline İş Doyumu & & & &, 290 & 4,972 &, $000^{8}$ & \\
\hline
\end{tabular}

${ }^{8} \mathrm{p}<0.01 ;{ }^{* *} \mathrm{p}<0.05$ düzeyinde anlamlıdır.

1. Bağımsız değişkenin (psikolojik dayanıklılık) bağımlı değişken (örgütsel vatandaşlık davranışı ve alt boyutları) üzerinde anlamlı bir etkisinin olması,

2. Bağımsız değişkenin (psikolojik dayanıklılık) aracı değişken (iş doyumu) üzerinde anlamlı bir etkisinin olması,

3. Aracı değişken (iş doyumu) analize katıldığında, bağımlı değişken (örgütsel vatandaşlık davranışı ve alt boyutları) ile bağımsız değişken (psikolojik dayanıklılık) arasında daha önce anlamlı olan ilişkinin, anlamlilik seviyesinin tamamen ortadan kalkması (tam aracılık - full mediation) ya da önceki seviyeye kıyasla azalması (k1smi aracılık - partial mediation) gerekmektedir. Ayrıca, aracılık etkisinin (beta değerindeki azalma miktarının) anlamlı olup olmadığ sobel testi ile analiz edilmiştir.

Tablo 4'te yer alan bulgular incelendiğinde; örgütsel vatandaşlık davranışı değişkeninin \%46.5'inin psikolojik dayanıklılık ve iş doyumu değişkenleri tarafından açıklandığı $\left(\mathrm{R}^{2}=, 465\right)$ ve \%99 güven aralığında anlamlı $(\mathrm{F}=112,910, \mathrm{p}=, 000)$ olduğu söylenebilir. Ayrıca, psikolojik dayanıklılık regresyon katsayısı Beta'nın değeri $(\beta=, 423)$, modele iş doyumu aracı değişkeninin katılması ile $(\beta=, 207)$ azalmıştır, ancak tamamen ortadan kalkmamıştır $(\mathrm{p}=, 000)$. Bu bulgular 1şı̆̆ında, 
“çalışanların psikolojik dayanıklılık düzeylerinin örgütsel vatandaşlık davranıșları üzerindeki etkisinde iş doyumunun aracılık rolü vardır" hipotezi $\left(\mathrm{H}_{4}\right)$ "klsmı aracılık etkisi vardır" olarak kabul edilmektedir.

Tablo 5 ile Model 1'deki bulgular incelendiğinde; diğerkâmlık değişkeninin \%27,7'sinin psikolojik dayanıklılık ve iş doyumu değişkenleri tarafindan açıklandığ1 (R2=,277) ve \%99 güven aralığında anlamlı $(F=112,910, p=, 000)$ olduğu söylenebilir. Ayrıca, psikolojik dayanıklılık regresyon katsayısı Beta'nın değeri $(\beta=, 292)$, modele iş doyumu aracı değişkeninin katılması ile $(\beta=, 114)$ azalmıştır, ancak tamamen ortadan kalkmamıştır $(\mathrm{p}=, 045) . \mathrm{Bu}$ bulgular 1şığında, hipotez (H4a) "kısmı aracılık etkisi vardır" olarak kabul edilmektedir. Model 2'deki bulgular incelendiğinde; vicdanlılık değişkeninin \%15'inin psikolojik dayanıklılık ve iş doyumu değişkenleri tarafindan açıklandığı $\left(\mathrm{R}^{2}=, 150\right)$ ve $\% 99$ güven aralığında anlamlı $(\mathrm{F}=22,955, \mathrm{p}=, 000)$ olduğu söylenebilir. Ayrıca, psikolojik dayanıklılık regresyon katsayısı Beta'nın değeri $(\beta=, 172)$, modele iş doyumu aracı değişkeninin katılması ile $(\beta=, 032)$ azalmıştır ve tamamen ortadan kalkmıştır $(\mathrm{p}=, 609)$. Bu bulgular 1şığında, hipotez $\left(\mathrm{H}_{4 \mathrm{~b}}\right)$ "tam aracılık etkisi vardır" olarak kabul edilmektedir. Model 3'teki bulgular incelendiğinde; nezaket değişkeninin \%31,1'inin psikolojik dayanıklılık ve iş doyumu değişkenleri tarafindan açıklandığı $\left(\mathrm{R}^{2}=, 311\right)$ ve \%99 güven aralığında anlamlı $(\mathrm{F}=58,724, \quad \mathrm{p}=, 000) \quad$ olduğu söylenebilir. Ayrıca, psikolojik dayanıklılık regresyon katsayısı Beta'nın değeri $(\beta=, 258)$, modele iş doyumu aracı değişkeninin katılması ile $(\beta=, 058)$ azalmıştır ve tamamen ortadan kalkmıştır $(\mathrm{p}=, 300)$. Bu bulgular 1şı ğında, hipotez $\left(\mathrm{H}_{4 \mathrm{c}}\right)$ "tam aracılık etkisi vardır" olarak kabul edilmektedir. Model 4'teki bulgular incelendiğinde; centilmenlik değişkeninin \%13,5'sinin psikolojik dayanıklılık ve iş doyumu değişkenleri tarafindan açıklandığ $\left(\mathrm{R}^{2}=, 135\right)$ ve $\% 99$ güven aralığında anlaml $(\mathrm{F}=20,313, \mathrm{p}=, 000)$ olduğu söylenebilir. Ayrıca, psikolojik dayanıklılık regresyon katsayısı Beta'nın değeri $(\beta=, 261)$, modele iş doyumu arac1 değişkeninin katılması ile $(\beta=, 156)$ azalmıştır, ancak tamamen ortadan kalkmamıştır $(\mathrm{p}=, 013)$. Bu bulgular 1şı̆̆ında, hipotez $\left(\mathrm{H}_{4 \mathrm{~d}}\right)$ "kısmı aracılık etkisi vardır" olarak kabul edilmektedir. Model 5 'teki bulgular incelendiğinde; sivil erdem değişkeninin \%23,8'inin psikolojik dayanıklılık ve iş doyumu değişkenleri tarafindan açıklandığ söylenebilir. Ayrıca, psikolojik dayanıklılık regresyon katsayısı Beta'nın değeri $(\beta=, 407)$, modele iş doyumu aracı değişkeninin katılması ile $(\beta=, 298)$ azalmıştır, ancak tamamen ortadan kalkmamıştır $(\mathrm{p}=, 000)$. Bu bulgular 1şı̆̆ında, hipotez $\left(\mathrm{H}_{4 \mathrm{e}}\right)$ "klsmı aracılık etkisi vardır" olarak kabul edilmektedir.

\section{TARTIŞMA}

Örgütler, güçlü yönlerini bilen ve bu yönlerini gelecekte daha iyi nasıl geliştirebileceklerini araştıran, psikolojik dayanıklılıkları yüksek olan çalışanlara ihtiyaç duyabilir. Ayrıca, işinden ve iş ortamından memnuniyeti yüksek çalışanlar, gönüllülük esasına dayalı ekstra rol davranışı olan örgütsel vatandaşlık davranışı sergileyebilirler.

Araştırmanın bulguları kapsamında; çalışanların psikolojik dayanıklılık düzeyleri ile örgütsel vatandaşlık davranışı ve iş doyumu arasında ve iş doyumu ile örgütsel vatandaşlik davranışı arasında pozitif ve anlamlı bir etkinin olduğu regresyon analizleriyle test edilmiştir. Çalışanların psikolojik dayanıklılık düzeylerinin örgütsel vatandaşlık davranışı ve iş doyumları üzerinde olumlu bir etkiye sahip olduğu görülmektedir. Psikolojik dayanıklılık düzeyleri yüksek olan bireylerin işten sağladı̆̆ 1 doyumun da yükseleceği söylenebilir. Böylece iş doyumu yüksek olan birey örgüte karşı daha olumlu ve daha yapıcı faaliyetlerde bulunabilir ve örgütü için tanımlanan biçimsel iş formu dışında faaliyetlerde bulunabilir. Alanyazında psikolojik dayanıklılık ile iş doyumu arasında yapılan bazı çalışmaların da aynı yönlü ilişkiyi desteklediği görülmektedir (Çetin \& Basım, 2011; Larrabee vd., 2010; Hansen, Buitendach \& Kanengoni, 2015). Yine aynı şekilde psikolojik dayanıklılık düzeyleri yüksek olan çalışanların kendisine tanımlanan resmi işleri yapmanın ötesinde rol ötesi davranışı olan gönüllülük esaslı örgütsel vatandaşlık davranışı gösterdikleri de vurgulanabilir. Alanyazında psikolojik dayanıklılık ile örgütsel vatandaşlık davranışı arasında yapılan bazı çalışmalarda da aynı yönlü ilişkiyi desteklenmiştir (Avey, Wernsing \& Luthans, 2008; Budak, 2015). Diğer yandan; Eşitlik, Bekleyiş ve İhtiyaç temelli kuramlara göre, iş doyumu yüksek olan bireyin iş motivasyonu ve iş performansının da yüksek olabileceği ve bunun rol ötesi davranış olan örgütsel vatandaşlık davranışını yükselteceği ifade edilebilir. Yine yazında yapılan çalışmalar bu sonucu desteklemektedir (Kasemsap, 2013; Y1lmaz, 2012; Chang, Chen \& Y1, 2008).

Çalışanların psikolojik dayanıklılık düzeylerinin örgütsel vatandaşlık davranışı ve alt boyutlarına etkisinde iş doyumlarının aracılık rolünü test etmek amacıyla hiyerarşik regresyon kullanılmıştır. Bulgulara göre; iş doyumunun örgütsel vatandaşlık davranışı ve alt boyutlarından diğerkâmlık, centilmenlik ve sivil erdem üzerinde kısmı aracılık etkisi olduğu, vicdanlılı ve nezaket boyutları üzerinde ise tam aracılık etkisinin olduğu görülmüştür. Araştırmanın temel amacı ve bu doğrultuda oluşturulan hipotezi olan "çalışanların psikolojik dayanıklılık düzeylerinin örgütsel 
vatandaşlık davranışı üzerindeki etkisinde iş doyumlarının aracılık rolü vardır" desteklenmektedir. Çalışanların psikolojik dayanıklılık düzeylerinin örgütsel vatandaşlık davranışı üzerindeki etkisinin önemli olmasının yanında, iş doyumunun da bu etkide önemli bir rolünün olduğu belirtilebilir. Aynı şekilde örgütsel vatandaşlık davranışı alt boyutları içinde bu durumdan bahsedilebilir. Özellikle, vicdanlılık ve nezaket boyutları üzerinde tam aracılık etkisine sahip olan iş doyumunun oldukça önemli olduğu söylenebilir. Örgütler, çalışanlarının psikolojik dayanıklılık düzeylerinin artırılmasına destek olmaları ve aynı zamanda yaptıkları işten tatmin olmalarını sağlamaları onların ödül beklemeksizin ve gönüllü olarak örgütsel vatandaşlık davranışı sergilemelerine neden olabilecektir. Yazında bu sonuçla ilgili herhangi bir kaynak bulunamadığından bir kıyaslama yapılamamıştır. $\mathrm{Bu}$ sebeple çalışmanın yazına katkı sağlayacağı, diğer araştırmalar ve araştırmacılar için yol göstereceği düşünülmektedir.

\section{KAYNAKÇA}

Akkoç, İ., Çalışkan, A. \& Turunç, Ö. (2012). Örgütlerde gelişim kültürü ve algılanan örgütsel desteğin iş tatmini ve iş performansına etkisi: Güvenin aracılık rolü. Yönetim ve Ekonomi, 19(1), 105-135.

Alessandri, G., Vecchione, M. \& Tisak, J. (2012). The utility of positive orientation in predicting job performance and organisational citizenship behaviors. Applied Psychology: An International Review, 61(4), 669-698.

Altunışık, R., Coşkun, R., Bayraktaroğlu, S. \& Yıldırım, E. (2004). Sosyal bilimlerde araştırma yöntemleri: SPSS uygulamalı. İstanbul: Sakarya Kitabevi.

Avey, J.B., Wernsing, T.S. \& Luthans, F. (2008). Can positive employees help positive organizational change? Impact of psychological capital and emotions on relevant attitudes and behaviors. The Journal of Applied Behavioral Science, 44(3), 48-70.

Avey, J.B., Luthans, F. \& Youssef, CM. (2010). The additive value of positive psychological capital in predicting work attitudes and behaviors. Journal of Management, 36, 430-452.

Avey, J.B., Reichard, J.R., Luthans, F. \& Mhatre, H.K. (2011). Meta-analysis of the impact of positive psychological capital on employee attitudes, behaviors, and performance. Human Resource Development Quarterly, 22(2), 127-152

Baron, M.R. \& Kenny, A.D. (1986). The moderatormediator variable distinction in social pyschological research. Conceptual, strategic and statistical considerations. Journal of Personality and Psychology, 51(6), 1173-1182.

Basım, N. \& Şeşen, H. (2006). Örgütsel vatandaşlık davranış1 ölçeği uyarlama ve karşılaştırma çalışması. Ankara Üniversitesi SBF Dergisi, 61(4), 83-101.

Basım, N. \& Çetin, F. (2011). Yetişkinler için psikolojik dayanıklılık ölçeğinin güvenilirlik ve geçerlilik çalışması. Türk Psikiyatri Dergisi, 22, 1-12.

Baş, G. \& Şentürk, C. (2011). İlköğretim okulu öğretmenlerinin örgütsel adalet, örgütsel vatandaşlık ve örgütsel güven algıları. Kuram ve Uygulamada Ĕ̌itim Yönetimi, 17(1), 29-62.

Beardslee, W.R. \& Podorefsky, M.A. (1998). Resilient adolescents whose parents have serious affective and other psychiatric disorders: Importance of selfunderstanding and relationships. The American Journal of Psychiatry, 145(1), 63-69.

Bilgin N. (1995). Sosyal psikolojide yöntem ve pratik çalışmalar. İstanbul: Sistem Yayıncılık. 
Bitmiş, G.M., Sökmen, A. \& Turgut, H. (2013). Psikolojik dayanıklılığın tükenmişlik üzerine etkisi: Örgütsel özdeşleşmenin aracılık rolü. Gazi Üniversitesi İktisadi ve İdari Bilimler Fakültesi Dergisi, 15(2), 27-40.

Bowling, N.A., Wang, Q. \& Li, H.Y. (2012). The moderating effect of core self-evaluations on the relationships between job attitudes and organisational citizenship behavior. Applied Psychology: An International Review, 61(1), 97-113.

Bozkurt, S. (2011). İnsan kaynakları uygulamaları, örgütsel vatandaşlık kavramı ve finansal performans arasındaki ilişkinin incelenmesi: Bankacıllk sektöründe bir araştırma. Yönetim, 22(70), 36-62.

Brayfield, A. H. \& Rothe, F. H. (1951). An index of job satisfaction. Journal of Applied Psychology, 5, 307311.

Bruck, S.C., Allen, D.T. \& Spector, E.P. (2002). The relation between work-family conflict and job satisfaction: a finer-grained analysis. Journal of Vocational Behavior, 60, 336-353.

Budak, G. (2015). Psikolojik dayanıklılık ve örgütsel adalet algısının örgütsel vatandaşlık davranışı üzerine etkisi (Yayınlanmamış Yüksek Lisans Tezi). Başkent Üniversitesi Sosyal Bilimler Enstitüsü, Ankara.

Buluç, B. (2008). Ortaöğretim okullarında örgütsel sağlık ile örgütsel vatandaşlık davranışları arasındaki ilişki. Türk Eğitim Bilimleri Dergisi, 6(4), 571-602.

Can, N. \& Özer, S. (2011). Eğitim örgütlerinde lider davranış biçimleri ile örgütsel vatandaşlık davranışı arasındaki ilişki (Nevşehir örneği). NEÜ Sosyal Bilimler Enstitüsü Dergisi, 1, 1-17.

Carvajal, R.R., Jiménez, M.B., Hermosilla, R.S., Bejarano, A.A. \& Vergel, I.A. (2010). Positive psychology at work: mutual gains for individuals and organizations. Revista de Psicología del Trabajo y de las Organizaciones, 26(3), 235-253.

Chiu, S.F., Tsai, M. \& Ching (2006). Relationships among burnout, job involvement, and organizational citizenship behavior. The Journal of Psychology, 140(6), 517-530

Clapp-Smith, R.O., Vogelgesang, G. \& Avey, J.B. (2009). Authentic leadership and positive psychological capital: The mediating role of trust at the meso-level of analysis. Journal of Leadership and Organization Studies, 15, 227-240.

Çetin, F. \& Basım, N. (2011). Psikolojik dayanıklılığın iş tatmini ve örgütsel bağlılık tutumlarındaki rolü. "Iss, Güç" Endüstri İlişkileri ve İnsan Kaynakları Dergisi, 13(3), 79-94.
Çetin, F. \& Basım, N. (2012). Örgütsel psikolojik sermaye: Bir ölçek uyarlama çalışması. Amme İdaresi Dergisi, 45(1), 121-137.

Çetin, Ş., Korkmaz, M. \& Çakmakçı, C. (2012). Dönüşümsel ve etkileşimsel liderlik ile lider-üye etkileşiminin öğretmenlerin örgütsel vatandaşlık davranış1 üzerindeki etkisi. Kuram ve Uygulamada Ĕ̌itim Yönetimi, 18(1), 7-36.

Chang, C.S., Chen, S. \& Y1, T.L. (2008). Raising nurses' job satisfaction through patient-oriented perception and organizational citizenship behaviors. Nursing Research, 60, 40-46.

Demirel, Y., Seçkin, Z. \& Özçınar, F.M. (2011). Örgütsel iletişim ile örgütsel vatandaşlık davranışı arasındaki ilişki üzerine bir araştırma. Ç. Ü. Sosyal Bilimler Enstitüsü Dergisi, 20(2), 33-48.

Donaldson, I.S. \& Ko, I. (2010). Positive organizational psychology, behavior, and scholarship: A review of the emerging literature and evidence base. The Journal of Positive Psychology, 5(3), 177-191.

Eğinli, T.A. (2009). Çalışanlarda iş doyumu: Kamu ve özel sektör çalışanlarının iş doyumuna yönelik bir araştırma. Atatürk Üniversitesi İktisadi ve İdari Bilimler Dergisi, 23(3), 35-52.

Erkuş, A. \& Fındıklı, M.A. (2013). Psikolojik sermayenin iş tatmini, iş performansı ve işten ayrılma niyeti üzerindeki etkisine yönelik bir araştırma. İstanbul Üniversitesi İşletme Fakültesi Dergisi, 42(2), 302-318

Erkutlu, V.H. (2015). Pozitif örgütsel davranış. Ankara: Akademisyen Kitabevi.

Finkelstein, M.A. (2011). Intrinsic and extrinsic motivation and organizational citizenship behavior: A functional approach to organizational citizenship behavior. Journal of Psychological Issues in Organizational Culture, 2(1), 19-34.

Foote, A.D. \& Tang, L.P.T. (2008). Job satisfaction and organizational citizenship behavior (OCB): Does team commitment make a difference in self-directed teams?. Management Decision, 46(6), 933-947.

Fox, S., Spector P.E., Goh, A., Bruursema, K. \& Kessler S.R. (2012). The deviant citizen: Measuring potential positive relations between counterproductive work behaviour and organizational citizenship behaviour. Journal of Occupational and Organizational Psychology, 85, 199-220.

Gooty, J., Gavin, M., Johnson, P., Frazier, L. \& Snow, D. (2009). In the eyes of the beholder: Transformational leadership, positive psychological capital and performance. Journal of Leadership and Organization Studies, 15, 353-357.

Gürbüz, S. (2006). Örgütsel vatandaşlık davranışı ile duygusal bağlılık arasındaki ilişkilerin belirlenmesine 
yönelik bir araştırma. Ekonomik ve Sosyal Araştırmalar Dergisi, 3(2), 48-75.

Gürbüz, S. (2010). Algılanan kurumsal imajın yöneticilerin bazı tutum ve davranışlarına etkisi. Selçuk Üniversitesi SBE Dergisi, 24, 229-240.

Gürbüz, S., Erkuş, A. \& Sığrı, Ü. (2010). İş tatmini ve iş performansının yeni öncülü: Temel benlik değerlendirmesi. Sosyal ve Beşeri Bilimler Dergisi, 2(1), 69-76.

Hansen, A., Buitendach, J.H. \& Kanengoni, H. (2015). Psychological capital, subjective well-being, burnout and job satisfaction amongst educators in the Umlazi region in South Africa. SA Journal of Human Resource Management, 3(1), 1-9.

Hemdi, M.A. \& Nasurdin, A.M. (2008). Investigating the influence of organizational justice on hotelemployees' organizational citizenship behavior intentions and turnover intentions. Journal of Human Resources in Hospitality \& Tourism, 7(1), 1-23.

Hodges, D.T. \& Clifton, O.D. (2004). Strengths-based development in practice. İçinde A.P. Linley \& S. Joseph (Ed.), Positive Psychology in Practice. New Jersey: John Wiley \& Sons, Inc.

Hungins, A. T. (2016). Resilience, job satisfaction and anticipated turnover in nurse leaders. The Journal of Nursing Management, 24(1), 62-69.

Iaffaldano, B., Michelle T. \& Muchinsky, P. M. (1985). Job satisfaction and job performance: A metaanalysis. Psychological Bulletin, 97(2), 251-273.

İrmiş, A. \& Gök, E.E. (2008). Az gelişmiş ülkelerde fason üretim ve örgütsel vatandaşlık olgusu. Akademik Incelemeler, 3(1), 193-219.

Jayaratne, S. \& Wayne A.C. (1984). Job satisfaction, burnout and turnover: A national survey. Social Work, 29, 448-453.

Jensen S.M. \& Luthans, F. (2006). Relationship between entrepreneurs' psychological capital and their authentic leadership. Journal of Managerial Issues, 18, 254-273.

Judge, T.A., Thoresen, C.J., Bono, J.E. \& Patton, G.K. (2001). The job satisfaction-job performance relationship: A qualitative and quantitative review. Psychological Bulletin, 127(3), 376-407.

Kasemsap, K. 2013. Innovative human resource practice: A unified framework and causal model of psychological empowerment, job satisfaction, organizational citizenship behavior, and organizational performance. International Proceedings of Economics Development and Research, 64, 51-54.
Katz, D. (1964). The motivational basis of organizational behavior. Behavioral Science, 9(2), 131-146

Keleş, Y. \& Pelit, E. (2009). Otel işletmesi işgörenlerinin örgütsel vatandaşlık davranışları: İstanbul'daki beş yıldızlı otel işletmelerinde bir araştırma. Ekonomik ve Sosyal Araştırmalar Dergisi, 5(2), 24-45.

Keleş, NH. (2011). Pozitif psikolojik sermaye: tanımı, bileşenleri ve örgüt yönetimine etkileri. Organizasyon ve Yönetim Bilimleri Dergisi, 3(2), 343-350.

Keser, A. (2006). Çağrı merkezi çalışanlarında iş yükü düzeyi ile iş doyumu ilişkisinin araştırılması. Kocaeli Üniversitesi Sosyal Bilimler Enstitüsü Dergisi, 11(1), 100-119.

Kılıç, C., Efeoğlu, İ.E., Mimaroğlu, H. \& Özgen, H. (2008). Adana ilindeki özel sağlı merkezlerinde çalışan personelin iş-aile yaşam çatışmasının örgütsel bağll1ık, iş doyumu ve iş stresine etkisi üzerine bir araştırma. C.. U. Sosyal Bilimler Enstitüsü Dergisi, 17(2), 241-254.

Lambert, E.G. (2010). The relationship of organizational citizenship behavior with job satisfaction, turnover intent, life satisfaction, and burnout among correctional staff. Criminal Justice Studies, 23(4), 361-380.

Larrabee, J.H., Wu, Y., Persily, C.A., Simoni, P.S., Johnston, P.A., Marcischak, T.L., Mott, C.L. \& Gladden, S.D. (2010). Influence of stress resiliency on $\mathrm{RN}$ job satisfaction and intent to stay. Western Journal of Nursing Research, 32(1), 81-102.

Lee, H.J., Iijima, Y. \& Reade, C. (2011). Employee preference for performance-related pay: predictors and consequences for organizational citizenship behaviour in a Japanese firm. The International Journal of Human Resource Management, 22(10), 2086-2109.

Lifeng, Z. (2007). Effects of psychological capital on employees' job performance, organizational commitment, and organizational citizenship behavior. Acta Psychologica Sinica, 16(2).

Linley, P.A., Joseph, S., Harrington, S. \& Wood, M.A. (2006). Positive psychology: Past, present,and (possible) future. The Journal of Positive Psychology, 1(1), 3-16.

Luthans, F. (2002). Positive organizational behavior: Developing and managing psychological strengths. Academy of Management Executive, 16(1), 57-72.

Luthans, F., Luthans, K. \& Luthans, C.B. (2004). Positive psychological capital: Beyond human and social capital. Business Horizons, 47(1), 45-50.

Luthans, F., Avey, J.B., Avolio, B.J., Norman, S.M. \& Combs, G.M. (2006). Psychological capital 
development: Toward a microintervention. Journal of Organizational Behavior, 27, 387-393.

Luthans, F., Youssef, C.M. \& Avolio, B.J. (2007). Psychological capital: Developing the human competitive edge. UK: Oxford University Press.

Luthans, F., Avolio, J.B., Avey, B.J. \& Norman, M.S. (2007). Positive psychological capital: Measurement and relationship with performance and satisfaction. Personnel Psychology, 60, 541-572.

Markóczy, L., Vora, D. \& Xin, K. (2009). Forbearance in organizational citizenship behaviour. The International Journal of Human Resource Management, 20(2), 321-347.

Murphy, G., Athanasou, J. \& King, N. (2002). Job satisfaction and organizational citizenship behaviour: A study of Australian human-service professionals. Journal of Managerial Psychology, 17(4), 287-297.

Naima, B. (1998). Job satisfaction, stress and coping strategies among Moroccan high school teachers. Mediterranean Journal of Educational Studies, 3(1), 3-33.

Organ, W. D. (1977). A reappraisal and reinterpretation of the satisfaction-causes-performance hypothesis. Academy of Management Review, 2, 46-53.

Organ, W. D. (1988). Organizational citizenship behaviour: The good soldier syndrome, MA: Lexington Books.

Organ, D.W. (1997). Organizational citizenship behavior: It's construct clean-up time. Human Performance, 10(2), 85-97.

Özer, S.P., Topaloğlu, T. \& Özmen, N.T.Ö. (2013). Destekleyici örgüt ikliminin, psikolojik sermaye ile iş doyumu ilişkisinde düzenleyici etkisi. Ege Akademik Bakıs, 13(4), 437-447.

Paillé, P. (2009). Assessing organizational citizenship behavior in the French context: evidence for the fourdimensional model. The Journal of Psychology, 143(2), 133-146

Peng, J., Jiang, X., Zhang J., Xiao, R., Song, Y., Feng, X., Zhang, Y. \& Miao, D. (2013). The impact of psychological capital on job burnout of Chinese nurses: The mediator role of organizational commitment. Public Library of Science One, 8(12), e84193

Peterson, S.J., Luthans, F., Avolio, B.J., Walumbwa, F.O. \& Zhang, Z. (2011). Psychological capital and employee performance: A latent growth modeling approach. Personnel Psychology, 64, 427-450.

Rafferty, A.E. \& Restubog, S.L.D. (2011). The influence of abusive supervisors on followers' organizational citizenship behaviours: The hidden costs of abusive supervision. British Journal of Management, 22, 270285.

Rego, A., Sousa, F., Marques, C. \& Cunha, P.M. (2011). Authentic leadership promoting employees' psychological capital and creativity. Journal of Business Research, 65, 429-437.

Roberge, M.E., Xu, Q.J. \& Rousseau, D.M. (2012). Collective personality effects on group citizenship behavior: Do diverse groups benefit more? Small Group Research, 43(4), 410-442.

Rurkkhum, S. \& Bartlett, K.R. (2012). The relationship between employee engagement and organizational citizenship behaviour in Thailand. Human Resource Development International, 15(2), 157-174.

Saari, M.L. \& Judge, A.T. (2004). Employee attitudes and job satisfaction. Human Resource Management, 43(4), 395-407.

Seligman, M.E.P. (2002). Positive psychology, positive prevention, and positive therapy. İçinde C.R. Snyder \& J.S. Lopez (Ed.), Handbook of positive psychology. New York: Oxford University Press.

Sparks, S., Corcoran, K., Nabors, L. \& Hovanitz, C. 2005. Subjective well-being and job satisfaction in nurses. Journal of Applied Social Psychology, 5(5), 922-938.

Sökmen, A. \& Boylu, Y. (2011). Örgütsel vatandaşlık davranışı cinsiyete göre farklılık gösterir mi? Otel işletmeleri açısından bir değerlendirme. Gaziantep Üniversitesi Sosyal Bilimler Dergisi, 10(1), 147-163.

Sünter, T.A., Canbaz, S., Dabak, Ş., Öz, H. \& Pekşen, Y. (2006). Pratisyen hekimlerde tükenmişlik, işe bağlı gerginlik ve iş doyumu düzeyleri. Genel Tip Dergisi, 16(1), 9-14.

Sahin, F. (2011). Liderin kültürel zekâsının astların örgütsel vatandaşlık davranışı ile iş doyumu üzerine etkisi. Savunma Bilimleri Dergisi, 10(2), 80-104.

Şeker, B.D. \& Zırhlıoğlu, G. (2009). Van Emniyet Müdürlügü kadrosunda çalışan polislerin tükenmişlik, iş doyumu ve yaşam doyumları arasındaki ilişkilerin değerlendirilmesi. Polis Bilimleri Dergisi, 11(4), 126.

Şeşen, H. (2010). Kontrol odağ1, genel öz yeterlik, iş tatmini ve örgütsel adalet algısının örgütsel vatandaşlık davranıșına etkisi: Ankara'da bulunan kamu kurumlarında bir araştırma. H.U. İktisadi ve Idari Bilimler Fakültesi Dergisi, 28(2), 195-220.

Tett, P.R. \& Meyer, P.J. (1993). Job satisfaction, organizational commitment, turnover intention, and turnover: Path analyses based on meta-analytic findings. Personnel Psychology, 46(2), 259-293. 
Turgut, H., Bitmiş, G. \& Sökmen, A. (2013). Psikolojik dayanıklılı̆̆ın işten ayrılma niyeti üzerine etkisi: kamu kurumu çalışanlarl üzerine bir araştırma. 12. Ulusal İşletmecilik Kongresi, Muğla.

Turunç, Ö. \& Çelik, M. (2010). Algılanan örgütsel desteğin çalışanların iş-aile, aile-iş çatışması, örgütsel özdeşleşme ve işten ayrılma niyetine etkisi: Savunma sektöründe bir araştırma. A.Ü. SBE Dergisi, 14(1), 209-232.

Walumbwa, O.F., Luthans, F., Avey, B.J. \& Oke, A. (2009). Authentically leading groups: The mediating role of collective psychological capital and trust. Journal of Organizational Behavior, 32(1), 4-24.

Wang, Y., Liu, L., Wang, J. \& Wang, L. (2012). Workfamily conflict and burnout among chinese doctors: The mediating role of psychological capital. Journal of Occupational Health, 54(3), 232-240.

Williams, J.L. \& Anderson, E.S. (1991). Job satisfaction and organizational commitment as predictors of organizational citizenship and in-role behaviors. Journal of Management, 17(3), 601-617.

Yıldırım, F. 2007. İş doyumu ile örgütsel adalet ilişkisi. Ankara Üniversitesi SBF Dergisi, 62(1), 253-278.

Y1lmaz, K. 2012. İlköğretim okulu öğretmenlerinin iş doyumu düzeyleri ile örgütsel vatandaşlık davranışları arasındaki ilişki. Anadolu Journal of Educational Sciences International, 2(2), 1-14.

Yücel, C. \& Samanc1, G. (2009). Örgütsel güven ve örgütsel vatandaşlık davranışı. Fırat Üniversitesi Sosyal Bilimler Dergisi, 19(1), 113-132.

Yücel, İ. \& Demirel, Y. (2012). Psikolojik güçlendirmenin örgütsel vatandaşlık davranışına etkisi üzerine bir araştırma. Kocaeli Üniversitesi Sosyal Bilimler Enstitüsü Dergisi, 23, 19-48. 